\title{
Research on the vertical distribution of Cadmium in Jiaozhou Bay waters
}

\author{
Dongfang Yang ${ }^{1,2,3, \text { a }}$, Shengtao Chen ${ }^{1}$, Baolei $\mathrm{Li}^{1}, \mathrm{Xiao} \mathrm{Geng}^{1}$ and \\ Zijun $\mathrm{Xu}^{1}$ \\ 1North China Sea Environmental Monitoring Center, SOA, Qingdao \\ 266033, China; \\ 2College of Life Science, Shanghai Ocean University, Shanghai, 201306, \\ China: \\ 3College of Chemistry and Environmental Science, Guizhou Minzu \\ University, Shanghai, 550025, China \\ adfyang_dfyang@126.com
}

\begin{abstract}
Based on investigation dada on Cadmium (Cd) in bottom waters in Jiaozhou Bay in 1982, this paper analyzed the vertical distribution and seasonal variation of $\mathrm{Cd}$ Results showed that The contents of Cd ranged from 0.13-0.53 $\mu$ g.L-1, which were meeting Grade I (1.00 $\mu$ g.L-1) in National Sea Water Quality Standard (GB 3097-1997). Cd contents in different seasons were in order of autumn $>$ spring $>$ summer. By means of vertical sedimentation, $\mathrm{Cd}$ contents in surface waters were closed to in bottom waters in different seasons. The distribution trends in surface and bottom waters were same in wet season, while were inverse in dry season.

Keywords: Cadmium, Vertical distribution, Seasonal variation, Transfer process, Jiaozhou Bay

\section{Introduction}

$\mathrm{Cd}$ in natural environment is exist as compound mode, and is always low content [1]. However, $\mathrm{Cd}$ is high toxic, and is harmful to bosoms. The discharge of $\mathrm{Cd}$ to environment is increasing with the rapid development of industry, leading to the rising of $\mathrm{Cd}$ pollution issue. Ocean is the sink of various pollutants. Understanding the distribution, source and transfer process of $\mathrm{Cd}$ in marine environment is essential to environmental protection and the sustainable development of ocean economic. Based on investigation data on $\mathrm{Cd}$ in waters in Jiaozhou Bay, this paper analyzed the vertical distribution, seasonal variation and transfer process of $\mathrm{Cd}$, and to provide bases for environmental management and remediation.
\end{abstract}

\section{Material and method}


Jiaozhou Bay $\left(35^{\circ} 55^{\prime}-36^{\circ} 18^{\prime} \mathrm{N}, 120^{\circ} 04^{\prime}-120^{\circ} 23^{\prime} \mathrm{E}\right)$ is a semi-closed bay located in the south of Shandong Province, eastern China (Fig. 1). The total area, average water depth and bay mouth depth $390 \mathrm{~km} 2,7 \mathrm{~m}$ and $3 \mathrm{~km}$, respectively. The bay has more than ten inflow rivers, including Haibo Rriver, Licun Rriver, Baisha Rriver, Dagu Rriver, and Loushan Rivers etc., all of which have seasonal features, and are playing roles of input channels of various pollutants [2].

The data was provided by North China Sea Environmental Monitoring Center. The survey was conducted in April, July, and October 1982. There were 5 monitoring sites in April, namely 083, 084, 121, 122 and 123 in the investigations in April, July and October. While for the investigation in July, there were 4 monitoring sites namely H37, H39, H40 and H41, respectively. Cd was monitored follow by National Specification for Marine Monitoring [3].

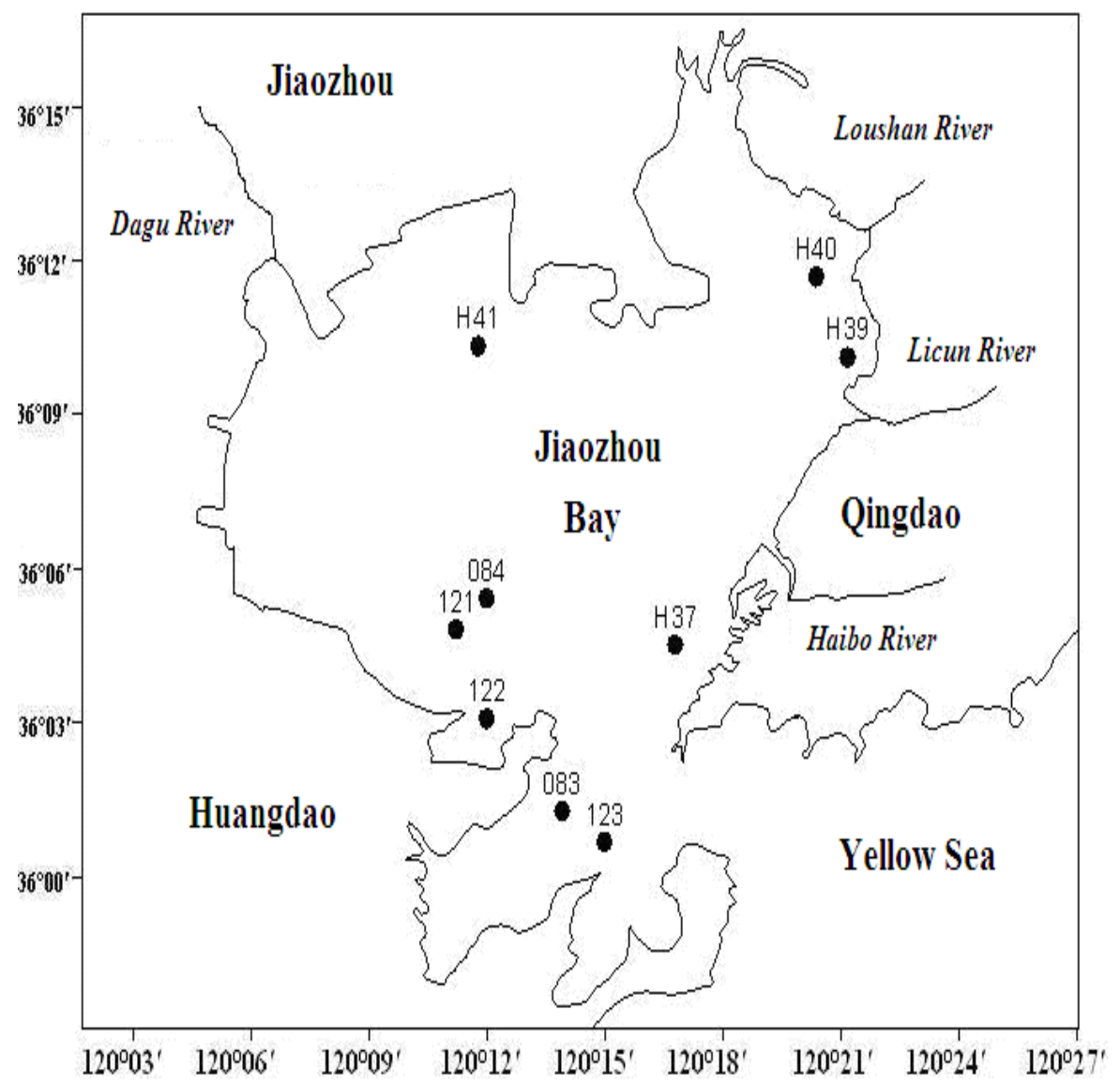

Fig.1 Geographic location and monitoring sites in Jiaozhou Bay

\section{Results and discussion}


Horizontal distribution of $\mathrm{Cd}$ contents in bottom waters. The content of $\mathrm{Cd}$ in bottom waters in Jiaozhou Bay ranged from 0.13-0.53 $\mu \mathrm{g} . \mathrm{L}^{-1}$. In April, Cd contents were increasing from the coastal waters in the southwest $\left(0.20 \mu \mathrm{g} . \mathrm{L}^{-1}\right)$ to the bay mouth $\left(0.44 \mu \mathrm{g} . \mathrm{L}^{-1}\right)$, which were inverse to the distribution in surface waters (Fig. 2). In July, Cd contents were decreasing from the coastal waters in the southwest $\left(0.24 \mu \mathrm{g} . \mathrm{L}^{-1}\right)$ to the bay mouth $\left(0.13 \mu \mathrm{g} . \mathrm{L}^{-1}\right)$, which were same as the distribution in surface waters (Fig.3). In October, $\mathrm{Cd}$ contents were decreasing from the coastal waters in the southwest $\left(0.53 \mu \mathrm{g} . \mathrm{L}^{-1}\right)$ to the bay mouth $\left(0.21 \mu \mathrm{g} . \mathrm{L}^{-1}\right)$, which were same as the distribution in surface waters (Fig. 4).

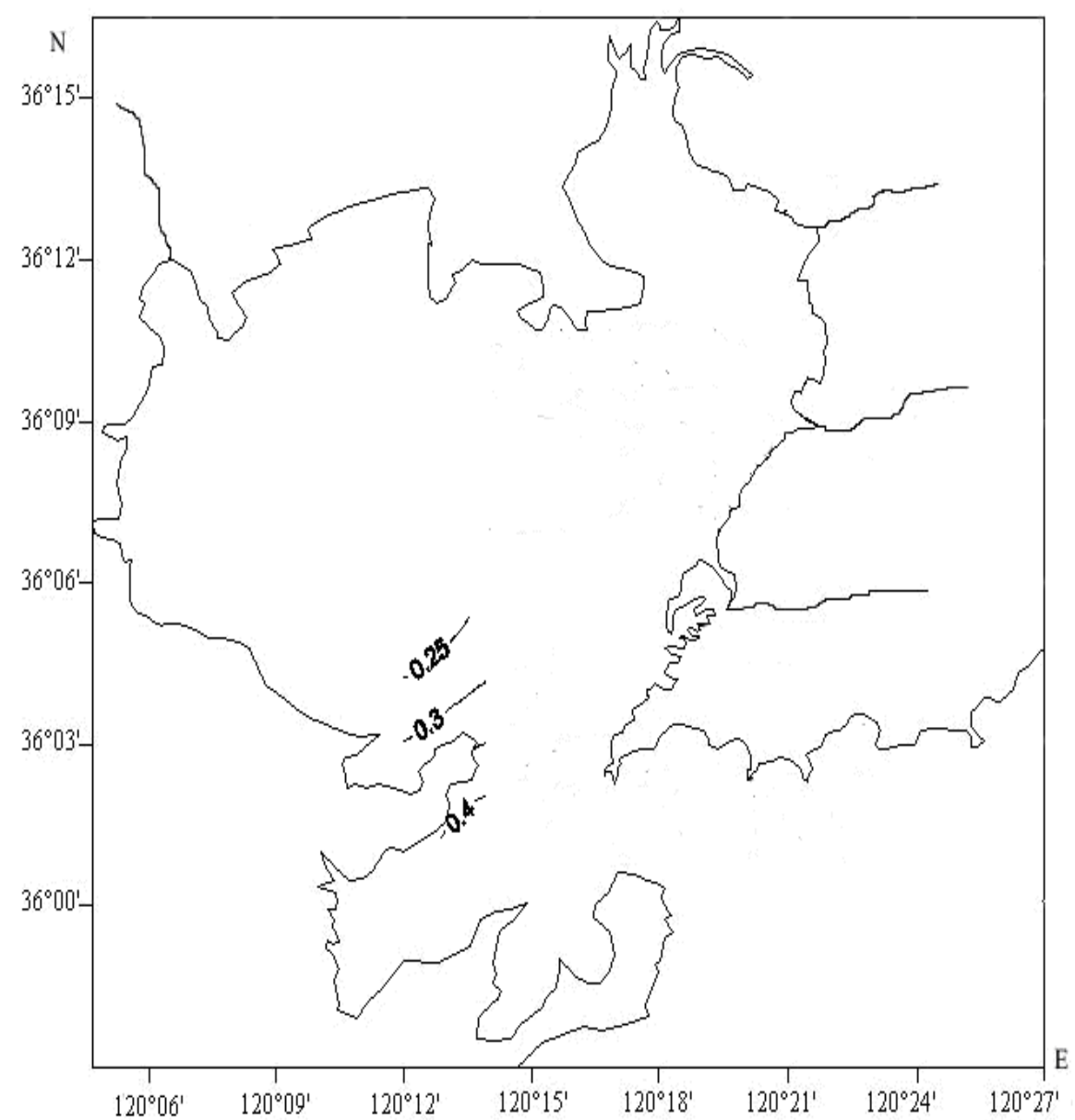

Fig. 2 Distributions of Cd contents in April 1982 in bottom waters in Jiaozhou Bay $/ \mu \mathrm{g} . \mathrm{L}^{-1}$ 


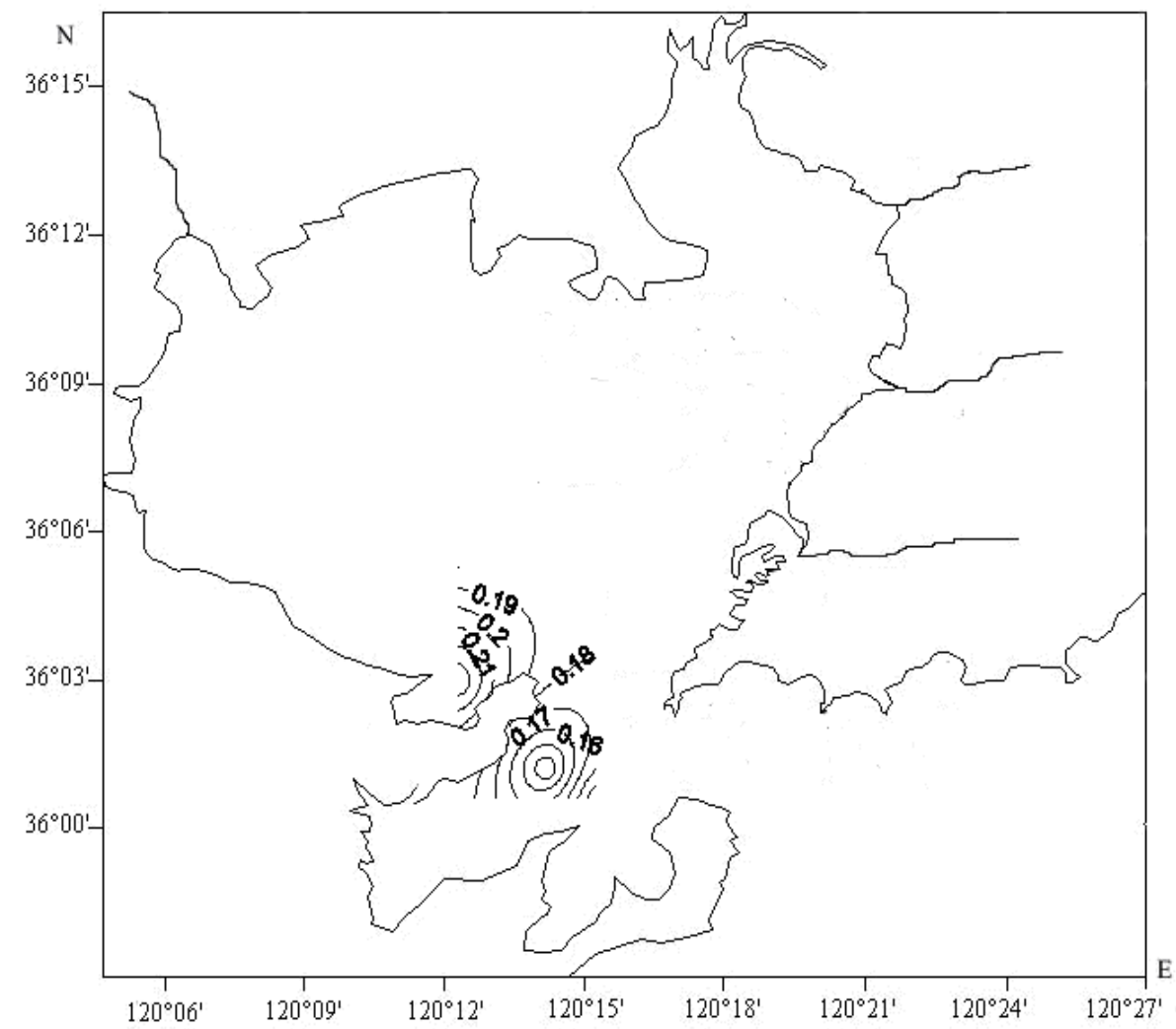

Fig. 3 Distributions of Cd contents in July 1982 in bottom waters in Jiaozhou Bay/ $\mu \mathrm{g} . \mathrm{L}^{-1}$ 


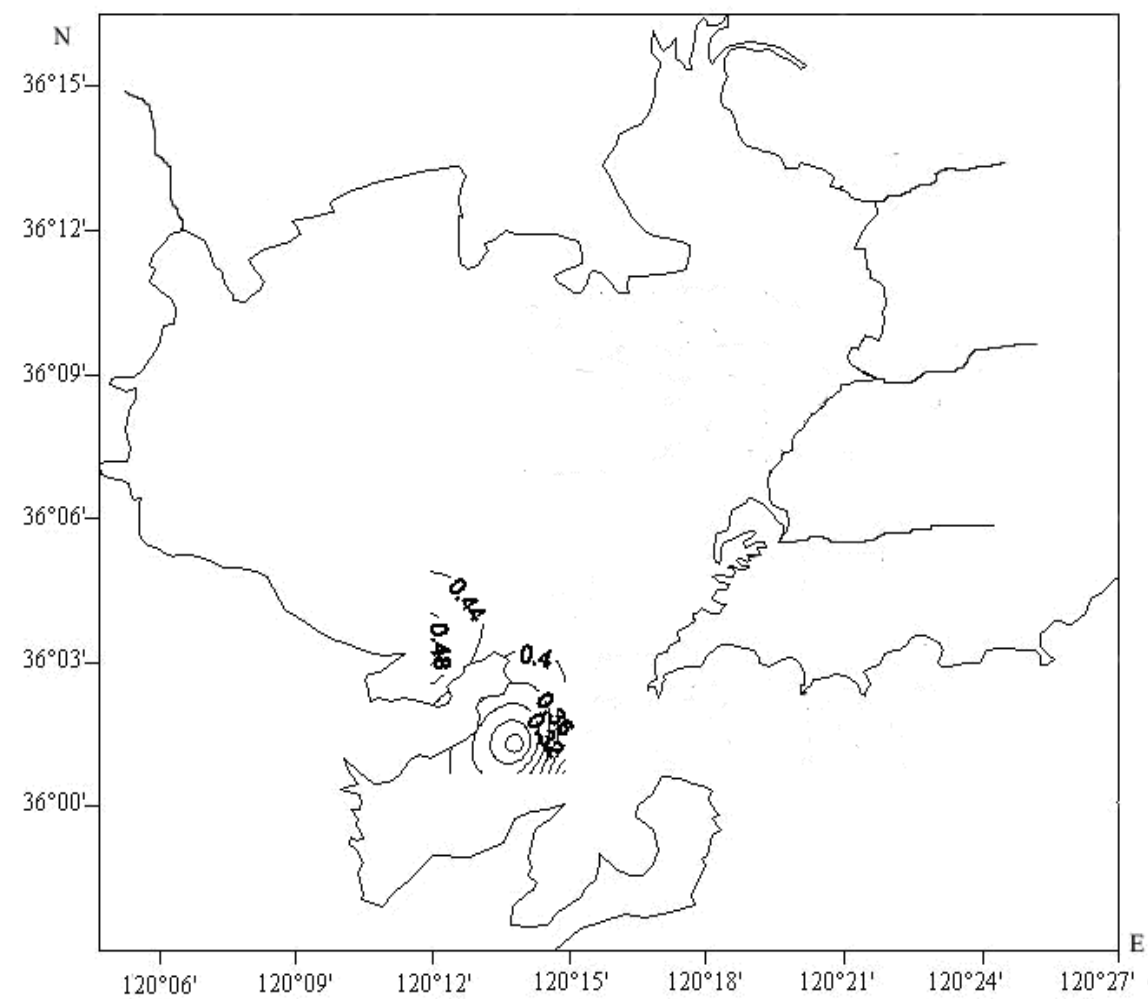

Fig. 4 Distributions of Cd contents in October 1982 in bottom waters in Jiaozhou

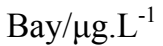

Seasonal variation. The content of $\mathrm{Cd}$ in April, July and October in surface waters in Jiaozhou Bay ranged from 0.11-0.38 $\mu \mathrm{g} . \mathrm{L}^{-1}, 0.12-0.52 \mu \mathrm{g} . \mathrm{L}^{-1}$ and $0.32-0.53 \mu \mathrm{g} . \mathrm{L}^{-1}$, respectively (Fig. 5). We defined April, June and October as spring, summer and autumn, respectively. It was obviously that $\mathrm{Cd}$ contents in different seasons in surface waters were in order of autumn $>$ summer $>$ spring. The content of $\mathrm{Cd}$ in April, June and October in bottom waters in Jiaozhou Bay ranged from $0.20-0.44 \mu \mathrm{g} . \mathrm{L}^{-1}, 0.13-0.24 \mu \mathrm{g} . \mathrm{L}^{-1}$ and $0.21-0.53 \mu \mathrm{g} . \mathrm{L}^{-1}$, respectively (Fig. 6). It was obviously that $\mathrm{Cd}$ contents in different seasons in bottom waters were in order of autumn $>$ spring $>$ summer. 


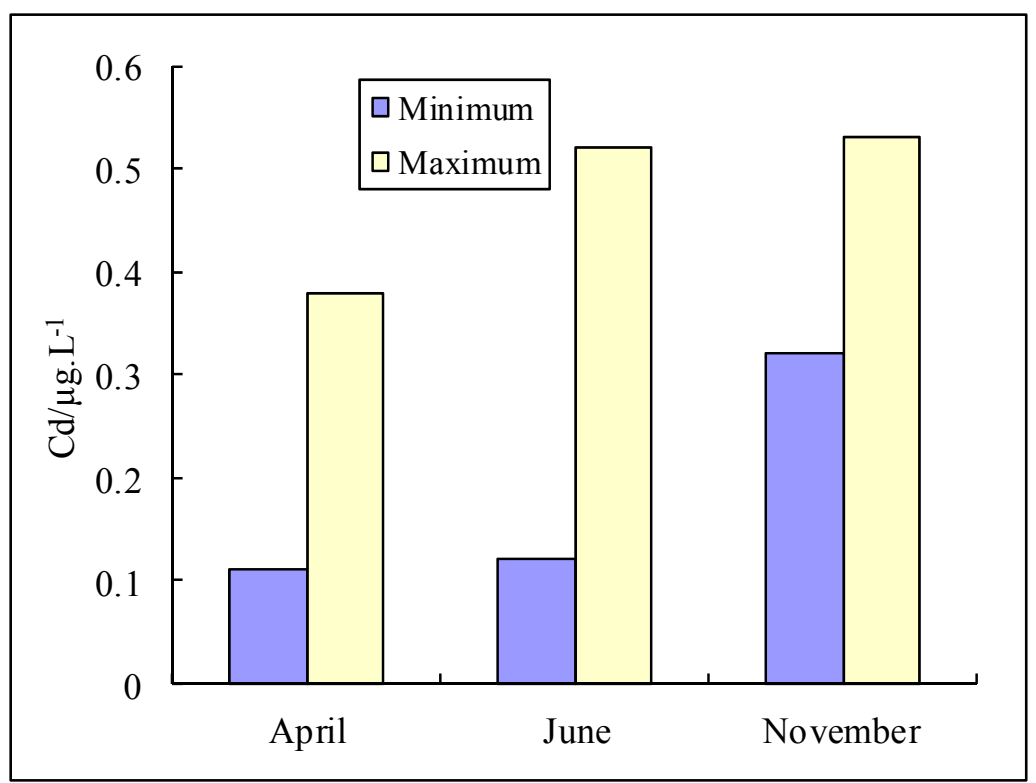

Fig. 5 The content of Cd in April, July and October in surface waters in Jiaozhou Bay

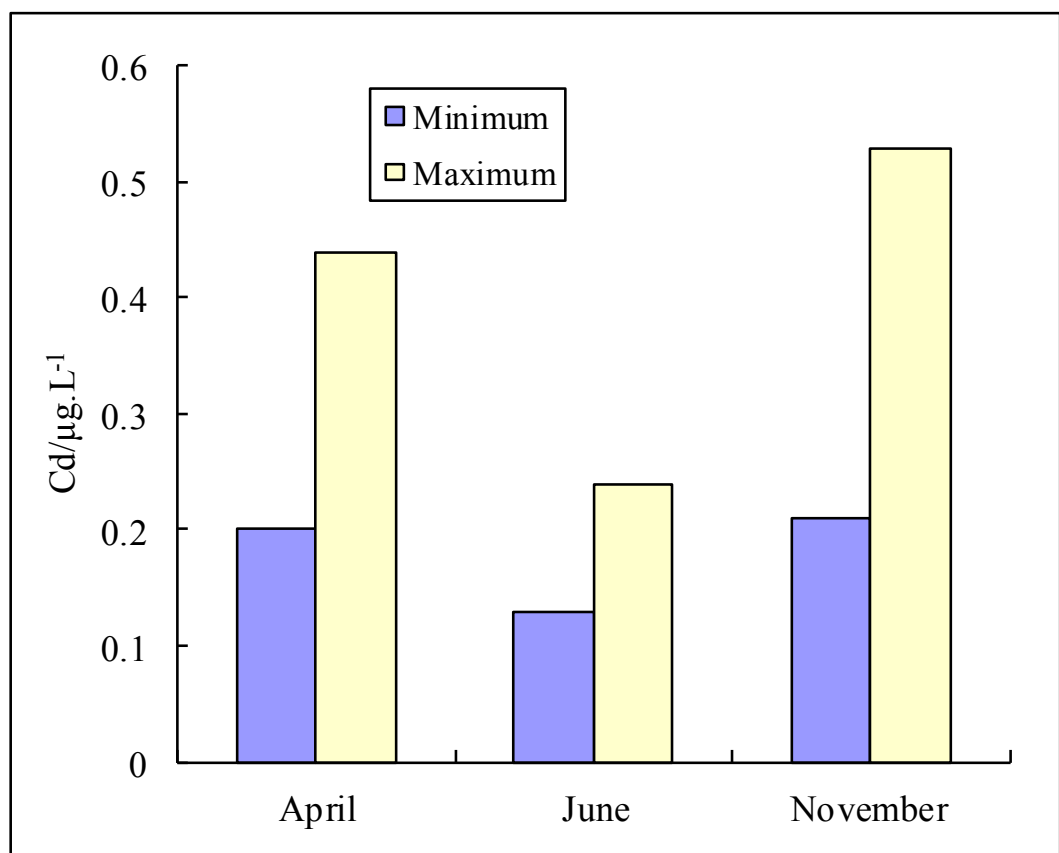

Fig. 6 The content of Cd in April, July and October in bottom waters in Jiaozhou Bay 
Horizontal variations of $\mathbf{C d}$ contents in waters. The content of $\mathrm{Cd}$ in surface waters in July were lowest (ranged from $0.11-0.38 \mu \mathrm{g} . \mathrm{L}^{-1}$ ), however, the content of $\mathrm{Cd}$ in bottom waters in July were relative high (ranged from 0.20-0.44 $\mu \mathrm{g} . \mathrm{L}^{-1}$ ). The content of $\mathrm{Cd}$ in surface waters in October were highest (ranged from $0.32-0.53 \mu \mathrm{g} . \mathrm{L}^{-1}$ ), and the content of $\mathrm{Cd}$ in bottom waters in October were also highest (ranged from $0.21-0.53 \mu \mathrm{g} . \mathrm{L}^{-1}$ ). The content of $\mathrm{Cd}$ in surface waters in July were relative high (ranged from $0.12-0.52 \mu \mathrm{g} . \mathrm{L}^{-1}$ ), yet the content of Cd in bottom waters in October were also highest (ranged from 0.13-0.24 $\mu \mathrm{g} . \mathrm{L}^{-1}$ ). In generally, Cd contents in different seasons were ranged from 0.11-0.35 $\mu \mathrm{g} . \mathrm{L}^{-1}$, which were showing no significant variations.

In April, $\mathrm{Cd}$ contents in surface waters were decreasing from coastal areas in the southwest of the bay $\left(0.38 \mu \mathrm{g} . \mathrm{L}^{-1}\right)$ to the bay mouth $\left(0.11 \mu \mathrm{g} . \mathrm{L}^{-1}\right)$, yet in bottom waters were increasing from coastal areas in the southwest of the bay $\left(0.20 \mu \mathrm{g} . \mathrm{L}^{-1}\right)$ to the bay mouth $\left(0.44 \mu \mathrm{g} . \mathrm{L}^{-1}\right)$. In June, Cd contents in surface waters were decreasing from coastal areas in the southwest of the bay $(0.52$ $\left.\mu \mathrm{g} . \mathrm{L}^{-1}\right)$ to the bay mouth $\left(0.12 \mu \mathrm{g} . \mathrm{L}^{-1}\right)$, and in bottom waters were also decreasing from coastal areas in the southwest of the bay $\left(0.24 \mu \mathrm{g} . \mathrm{L}^{-1}\right)$ to the bay mouth $\left(0.13 \mu \mathrm{g} . \mathrm{L}^{-1}\right)$. In October, Cd contents in surface waters were decreasing from coastal areas in the southwest of the bay $\left(0.53 \mu \mathrm{g} \cdot \mathrm{L}^{-1}\right)$ to the bay mouth $\left(0.32 \mu \mathrm{g} . \mathrm{L}^{-1}\right)$, and in bottom waters were also decreasing from coastal areas in the southwest of the bay $\left(0.53 \mu \mathrm{g} . \mathrm{L}^{-1}\right)$ to the bay mouth $\left(0.21 \mu \mathrm{g} . \mathrm{L}^{-1}\right)$. In generally, the distributions of $\mathrm{Cd}$ contents in surface and bottom waters were same in June and October, yet were different in April.

Transfer process of $\mathbf{C d}$ contents in waters. The content of $\mathrm{Cd}$ in surface waters in April, July and October ranged from 0.11-0.38 $\mu \mathrm{g} . \mathrm{L}^{-1}, 0.12-0.52 \mu \mathrm{g} . \mathrm{L}^{-1}$ and $0.32-0.53 \mu \mathrm{g} . \mathrm{L}^{-1}$, respectively. Cd contents in surface waters were closed to in bottom waters in different seasons, indicated that $\mathrm{Cd}$ contents in bottom waters might be determined by $\mathrm{Cd}$ contents in surface waters. The growth and reproduction of marine organism is beginner in spring and reach the climax in summer [4]. Due to the reproduction of marine organism especially phytoplankton, a large amount of colloid was produced, which were able to enhance the absorption of $\mathrm{Cd}$ to the suspended particles, leading to the rapid increasing of vertical sedimentation of $\mathrm{Cd}$. In wet season, a lot of $\mathrm{Cd}$ was inputted to the bay from the rivers, and the distributions of $\mathrm{Cd}$ in surface and bottom waters were tending to be same by means of vertical sedimentation and river flow. In dry season, Cd contents in surface waters were mainly determined by water exchange of the bay, while $\mathrm{Cd}$ contents in bottom waters were mainly determined by vertical sedimentation. Due to the input of Cd was limited in dry season, the distributions of $\mathrm{Cd}$ in surface and bottom waters were inverse.

\section{Conclusion}

The content of $\mathrm{Cd}$ in April, July and October in bottom waters in Jiaozhou

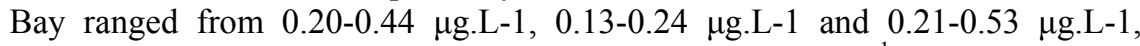
respectively. Cd contents were meeting Grade I $\left(1.00 \mu \mathrm{g} . \mathrm{L}^{-1}\right)$ in National Sea 
Water Quality Standard (GB 3097-1997), indicated that the pollution level of Cd in Jiaozhou Bay was very low in 1982.

It was obviously that $\mathrm{Cd}$ contents in different seasons in surface waters were in order of autumn $>$ summer $>$ spring, while in bottom waters were in order of autumn $>$ spring $>$ summer. The input of $\mathrm{Cd}$ to the bay was relatively higher in wet season than in dry season, because the plenty rainfall-runoff in wet season could deliver more $\mathrm{Cd}$ to rivers as well as the bay.

The input of $\mathrm{Cd}$ from the rivers was increasing in wet season, and the distributions of $\mathrm{Cd}$ in surface and bottom waters were tending to be same by means of vertical sedimentation and river flow. In dry season, $\mathrm{Cd}$ contents in surface waters were mainly determined by water exchange of the bay, while $\mathrm{Cd}$ contents in bottom waters were mainly determined by vertical sedimentation. Due to the input of $\mathrm{Cd}$ was limited in dry season, the distributions of $\mathrm{Cd}$ in surface and bottom waters were inverse.

\section{Acknowledgement}

This study was supported by Special Scientific Research Fund of Marine Public Welfare: Research on surveillance and monitoring of terrigenous and atmospheric sources heavy metal pollution in the North Sea(201105015-4), and Scientific Research Found of Director of North China Sea Environmental Monitoring Center (05EMC16).

\section{References}

[1] Dongfang Yang, Zhenhui Gao, Jingya Sun, Hairong Cao and Xiangqun Liu: Coast. Engin., Vol. 27(2008), p. 48-53. (in Chinese)

[2] Dongfang Yang, Yu Chen, Zhenhui Gao, Jing Zhang and Fan Wang: Chin. J. OceanoL. LimnoL., Vol. 23(2005), p. 72-90.

[3] China's State Oceanic Administration: The specification for marine monitoring (Ocean Press, Beijing 1991). (in Chinese)

[4] Dongfang Yang, Fan Wang, Zhenhui Gao, Wenlin Cui and Suxia Huo: Mar. Sci., Vol. 28(2004), p.71-74.(in Chinese) 